\section{Bright ideas}

\section{John Hall}

A PLEA for long term plans to use solar energy rather than entering a "Faustian bargain" to employ a nuclear technology was made by Professor D. Bryce-Smith (Department of Organic Chemistry, University of Reading) at the inaugural meeting of the United Kingdom section of the International Solar Energy Society in London recently. Professor BryceSmith urged a change in the climate (of opinion) so that short term economic considerations which dictated a nuclear strategy should not prevent the investment of money in a long term energy solution based on the power of the Sun. It was an appeal calculated to meet with immediate approval, since it was delivered to a meeting which filled the lecture theatre of the Royal Institution to overflowing with devotees of the solar economy.

What the faithful witnessed, apart from this brief obloquy against a nuclear power programme, was a quartet of lectures on solar possibilities, nicely illustrated with a slide show, and a clutch of demonstrations managed by Professor Sir George Porter in the best theatrical traditions of the institution. The only spontaneous round of applause during the entire meeting was accorded to a model railway engine which obligingly described a circuit whenever a bright light was directed on to its battery of photovoltaic cells. Alas, a further setpiece, meant to illustrate how light energy might be stored by a reversible process of chemical change, failed to function on account of technicality, and though belief in the theory can scarcely have been suspended, in many minds there was a distinet sense of pique at having been cheated of a spectacle. (Why is an elementary demonstration of a footling principle received like a virtuoso performance of conjuring by an assembly specifically equipped to see the simplicity of the feat? That is showbusiness.)

Gadgetry apart, Sir George made the point that although photochemical energy conversion might be a going concern in the field of space engineering, it is distinctly unpractical on economic grounds for generating power on terra firma. Apparently, the cost of making a $1 \mathrm{kw}$ plant, using pure silicon crystals, is something in the region of $£ 1,600$. Polycrystals make the proposition cheaper, and metallurgical silicon is capable of offering a rate of $£ 2$ per kw of output. But given this cost, and the facts that the most efficient cell of this kind only converts $14 \%$ of the solar energy falling on it, and that this is difficult to store, a good deal of work needs to be done before photochemical energy conversion can make a sizeable contribution to the economy.

Professor J. K. Page (Department of Building Sciences, University of Sheffield) also made the point that the central research issue in solar energy is the question of storage. Speaking about the arehitectural requirements of successful solar usage, Professor Page pointed out that when we really want energy, in winter, the Sun does not offer all that much; and in summer we do not want all that is available.

$\mathrm{He}$ also, however, indicated that any reservations one might harbour about the unreliability of British summers is not in itself an argument against our benefiting from solar radiation, since direct sunlight is not essential to energy conversion; diffuse energy is available throughout the year and could be used in various ways. But, Professor Page suggested, perhaps the first priority is to conserve rather than harness the energy actually falling on the Earth. (In Australia in one year the amount of energy arriving from the Sun is equivalent to the total of the planet's reserves of fossil fuels, so they say.) The need, then, is to build houses which let in the heat when it is around and hang on to it as long as possible.

In the same area of bending the mind on comparisons of solar and conventional energy sources, Dr D. O. Hall (King's College, London) contended that the amount of biologically useful solar energy falling on the Earth in three days is equivalent, yes, to the total of the planet's proven energy reserves. Concentrating on photobiological energy conversion, Dr Hall calculated that if the sunlight falling on the United States in one year could be converted at $10 \%$ efficiency, only $1.5 \%$ of the land area would have been sufficient to provide the country's total energy requirements for 1970; and meanwhile, back in Australia, only about $0.03 \%$ of the land mass could have supplied the nation's needs.

Naturally, an obstacle to the realisation of this economic miracle is the harvesting and burning of the energyrich products of photosynthesis. It would be a big job. Among priorities to improve the utilisation of solar encrgy by biological means, Dr Hall suggested the fermentation and pyrolysis of plant material to produce liquid fuels and gases; genetic engineering to produce plants which are more efficient as converters by photosynthesis, or plants which might be made to produce fatty acids or proteins; and the direct production of hydrogen by means of a photosynthetic system using water as the electron donor.

The ready production of cheap hydrogen (Dr Hill has not been the first to observe) would herald a new age of energy usage. Hydrogen obtained by photobiological means would use an inexaustible supply of energy (solar) and an inexhaustible supply of reagent (water) to produce a non-polluting energy. What price the new millenim?

\section{Nader embarrasses the US AEC}

\section{Colin Norman, Washington}

Critics of nuclear power in the United States have been engaged in the past two weeks in a brutal public battle with officials of the US Atomic Energy Commission over the safety of American light water reactors. The battle took place in the committec room of the Joint Committee on Atomic Energy, whose members were supposed to be holding the ring but ended up weighing in heavily on the side of the AEC. The charges and countercharges traded during the hearings are by now familiar stuff, but at least one attack grabbed headlines and put the AEC publicly on the defensive.

Ralph Nader, scourge of the automobile industry and consumer advocate par excellence, launched a blistering attack on the joint committee itself because "its zeal for promoting nuclear power has so overshadowed its responsibility to assure public safety that it has put at risk not only this generation, but a hundred generations to come". Nader also released an internal AEC task force report on the safety of nuclear power plants which, he said, shows that AEC officials have been "misrepresenting the facts" when they have assured the public of the safety of nuclear reactors.

AEC officials responded with some embarrassment to the disclosure of the task force report, suggesting that Nader had an early draft and that he was drawing false conclusions from the material it contained. Their response was to polish the report up and get it into the public domain as quickly as possible. They hope to publish a final version of the report sometime this week.

Nevertheless, Nader clearly scored points by unveiling the report in this manner. The task force, Nader said, "does not believe that there is the required confidence level that the probability for (a major) accident is one in a million or less per reactor year". Just a few days before Nader made his statement, Dr Dixy Lee Ray, the Chairman of the AEC, had indeed put forward the one-in-a-million suggestion as the basis for her contention that nuclear power plants are safer than most other forms of power generators.

The task force, Nader said, "assembled the most disturbing evidence of safety problems at US nuclear power 